\title{
Multitarget Activities of Kleeb Bua Daeng, a Thai Traditional Herbal Formula, Against Alzheimer's Disease
}

\author{
Chantha Chheng ${ }^{1}$, Pornthip Waiwut ${ }^{2}$, Kusawadee Plekratoke ${ }^{1}$, Yaowared Chulikhit ${ }^{1}$, \\ Supawadee Daodee ${ }^{1}$, Orawan Monthakantirat ${ }^{1}$, Supaporn Pitiporn ${ }^{3}$, Natdanai Musigavong ${ }^{3}$, \\ Pakakrong Kwankhao ${ }^{3}\left[\right.$ and Chantana Boonyarat ${ }^{1, *}$ (i) \\ 1 Faculty of Pharmaceutical Sciences, Khon Kaen University, Khon Kaen 40002, Thailand; \\ chheng_chantha72@yahoo.com (C.C.); kusawadee2535@gmail.com (K.P.); yaosum@kku.ac.th (Y.C.); \\ csupawad@kku.ac.th (S.D.); oramon@kku.ac.th (O.M.) \\ 2 Faculty of Pharmaceutical Sciences, Ubon Ratchathani University, Ubon Ratchathani 34190, Thailand; \\ pwaiwut79@yahoo.com \\ 3 Chao Phya Abhaibhubejhr Hospital, Prachin Buri 25000, Thailand; spitiporn@yahoo.com (S.P.); \\ mnatdanai@hotmail.com (N.M.); pakakrong2@gmail.com (P.K.) \\ * Correspondence: chaboo@kku.ac.th; Tel.: +66-81-3073313 or +66-43-202305
}

Received: 10 April 2020; Accepted: 23 April 2020; Published: 25 April 2020

\begin{abstract}
The Kleeb Bua Daeng formula (KBD) is a Thai traditional medicine for brain health promotion. On the basis of the activities of its individual components, the KBD could have good potential for the treatment of Alzheimer's disease (AD). Herein, we investigated the KBD as an AD treatment. The ethanol extracts of KBD and its components, i.e., Nelumbo nucifera (NN), Piper nigrum fruits (BP), and the aerial part of Centella asiatica (CA) exhibited antioxidant activity, as determined by both ABTS and DPPH assays. The Ellman's assay revealed that the KBD, NN, and BP showed an ability to inhibit acetylcholinesterase. The thioflavin T assay indicated that the KBD, NN, BP, and CA inhibited beta-amyloid aggregation. The neuroprotection and Western blot analysis revealed that the $\mathrm{KBD}$ reduced $\mathrm{H}_{2} \mathrm{O}_{2}$-induced neuronal cell death by inhibiting the expression of pro-apoptotic factors, i.e., cleaved caspase- 9 and -3, p-P65, p-JNK, and p-GSK-3 $\beta$, as well as by inducing expression of anti-apoptotic factors, i.e., $\mathrm{MCl}_{1}, \mathrm{BCl}_{\mathrm{xl}}$, and survivin. Furthermore, the $\mathrm{KBD}$ could improve scopolamine induced memory deficit in mice. Our results illustrate that the KBD with multimode action has the potential to be employed in AD treatment. Thus, the KBD could be used as an alternative novel choice for the prevention and treatment of patients with AD.
\end{abstract}

Keywords: antioxidant; acetylcholinesterase inhibition; beta-amyloid aggregation; neuroprotection; Nelumbo nucifera; Piper nigrum; Centella asiatica

\section{Introduction}

Alzheimer's disease (AD) is a multifactorial neurological disorder categorized by memory impairment, progressive decline in cognitive functions, and changes in behaviors and moods [1]. The incidence rate of $\mathrm{AD}$ has presented an exponential increase, particularly in people over 65 years of age; the disease currently affects over 33 million people worldwide [2-4]. Thus, AD is essentially a troublesome disease for the public health systems of the world.

The pathogenesis of AD follows numerous pathways which include deficiency of acetylcholine neurotransmitters [5], extracellular accumulation of beta amyloid plaques [6], intracellular deposit of neurofibrillary tangles $[7,8]$ and oxidative stress leading to neuronal cell death $[9,10]$. Over the past decades, many pharmacological strategies have been devoted to target these pathways, including both 
cholinergic and noncholinergic interventions [11,12]. The current therapeutic approaches for AD include the following: (a) acetylcholinesterase (AChE) inhibitors such as donepezil, rivastigmine, and galantamine and (b) the NMDA receptor antagonist, memantine [13]. However, while these drugs can be used for reducing symptoms, they are not effective for curing AD. Therefore, an effective pharmacotherapy against AD is urgently needed.

Due to the multiple pathways involved in the AD pathogenesis, the classical single-target approach that modulates one target is insufficient. Therefore, searching for candidates that target multiple stages of the pathogenesis cascade has become an effective strategy for designing pharmacotherapy against AD [14-16]. Thus, natural products composed of diverse phytochemical constituents, with multi-action or synergistic effects targeting multiple sites of the pathogenic cascade of $\mathrm{AD}$, could afford additional benefits for AD therapy [17-19].

The Kleeb Bua Daeng formula (KBD) has been used for a long time by local healers in Thailand as a multi-herb folk medicine for the treatment of patients who have declining memory function and insomnia. Since June 2013, the KBD has been prescribed by doctors in the Chao Phya Abhaibhubejhr Hospital, Thailand as a traditional medicine for brain tonic, sleep aid, mood stabilizer, and relaxation [20]. The KBD consists of the following three components: (i) Nelumbo nucifera petal (NN), (ii) Piper nigrum fruit (BP), and (iii) the aerial part of Centella asiatica (CA) mixed in a ratio of 1:1:1 (dry weight). Interestingly, each component of the KBD has been reported to have biological activity relevant to AD. Nelumbo nucifera has been extensively used as a component of traditional Thai, Chinese, Indian, Japanese, and Korean medicines [21]. Several investigations have reported that different parts of NN have activities related to AD patients' cognitive functions, including inhibition of $\mathrm{AChE}$ and $\beta$-site APP cleaving enzyme 1 (BACE1) [22]. In addition, $\mathrm{NN}$ reversed scopolamine-induced cognitive impairment in mice by increasing choline acetyltranferase (ChAT) expression [23]. Piper nigrum, or black pepper, has been widely utilized in several traditional medicine systems such as the Unani and Ayurvedic systems [24]. Black pepper has been reported as a potential treatment for cognitive dysfunction and neurodegeneration in AD [25-27]. Centella asiatica has been used for a long time in Ayurvedic traditions as a brain tonic and a memory enhancer [28]. There is evidence to show that, in animal models, CA could enhance memory retention and improve learning performance. The mechanisms for enhancing the cognitive function of CA have included the reduction of $B$-amyloid aggregation and protection of brain damage $[29,30]$. On the basis of the activities of its components, the KBD could have good potential as a novel treatment for AD. However, there has been no previous study investigating the $\mathrm{KBD}$ as a therapeutic for $\mathrm{AD}$.

This current study has investigated the effects of the KBD and its components on the following four targets in the pathological cascade of AD: (i) antioxidant activity, (ii) cholinesterase function, (iii) beta amyloid aggregation, and (iv) neuroprotection in vitro. The expression levels of proteins involved in neuronal cell death were determined in order to understand the mechanism of neuroprotection. Finally, the effects of the KDB on cognitive function were investigated in a scopolamine-induced cognitive-deficit mouse model.

\section{Results}

\subsection{Total Phenolic and Total Flavonoid Contents}

Phenols and flavonoids from plants can demonstrate several pharmacological activities. In order to study the relationship between activities and phytochemicals, the total phenolic and total flavonoid contents in ethanolic extracts of the KBD and its constituents were determined, and the results are shown in Table 1. 
Table 1. Total phenolic and flavonoid contents in the Kleeb Bua Daeng formula (KBD) and its components. The total phenolic and flavonoid contents of each extract are shown as $\mu \mathrm{g}$ of gallic acid equivalents per mg of extract ( $\mu \mathrm{g} \mathrm{GAE} / \mathrm{mg}$ Extract) and as $\mu \mathrm{g}$ of quercetin equivalents per mg of extract ( $\mu \mathrm{g} \mathrm{QE} / \mathrm{mg}$ Extract), respectively. Data are represented as mean $\pm \operatorname{SD}(n=3)$. Different letters in the same column are significantly different $(p<0.05)$.

\begin{tabular}{ccc}
\hline Samples & $\begin{array}{c}\text { Total Polyphenols } \\
(\mu \mathrm{g} \mathrm{GAE} / \mathbf{m g} \text { Extract })\end{array}$ & $\begin{array}{c}\text { Total Flavonoids } \\
(\boldsymbol{\mu g} \mathbf{Q} \text { QE/mg Extract })\end{array}$ \\
\hline KBD & $22.57 \pm 0.63^{\mathrm{a}}$ & $31.17 \pm 1.48^{\mathrm{a}}$ \\
Nelumbo nucifera $(\mathrm{NN})$ & $43.85 \pm 0.46^{\mathrm{b}}$ & $33.83 \pm 2.22^{\mathrm{a}}$ \\
Pipper nigrum $(\mathrm{BP})$ & $29.98 \pm 0.63^{\mathrm{c}}$ & $42.12 \pm 5.54^{\mathrm{b}}$ \\
Centella asiatica $(\mathrm{CA})$ & $12.64 \pm 0.25^{\mathrm{d}}$ & $19.21 \pm 0.59^{\mathrm{c}}$ \\
\hline
\end{tabular}

\subsection{Antioxidant Activities}

The alleviation of oxidative stress is a crucial strategy in designing agents for AD treatment. The antioxidant activities of the ethanol extracts of the KBD and its constituents were examined by using the ABTS and DPPH radical scavenging assays. The ability of extracts to scavenge radicals is shown as $\mathrm{IC}_{50}$, the test compound concentration that resulted in 50\% inhibition of free radicals. The KBD extract scavenged both ABTS and DPPH radicals with $\mathrm{IC}_{50}$ values of $0.90 \pm 0.06$ and $0.62 \pm 0.06 \mathrm{mg} / \mathrm{mL}$, respectively, as shown in Table 2. Trolox, used as a reference standard, could scavenge ABTS and DPPH radicals with $\mathrm{IC}_{50}$ of $73.14 \pm 2.71$ and $22.91 \pm 0.16 \mu \mathrm{M}$, respectively. To compare the activities among the components, the $\mathrm{KBD}$ extract at $3 \mathrm{mg} / \mathrm{mL}$ and its components at equivalent amounts (NN, BP, and CA at $1 \mathrm{mg} / \mathrm{mL}$ ) were assayed. The NN extract possessed the most potent radical scavenging activity, followed by BP and CA (Figure 1). Our results showed that the radical scavenging activity of the KBD is mainly provided by NN.

Table 2. In vitro ABTS and DPPH radical scavenging and acetylcholinesterase (AChE) inhibitory actions of the ethanol extracts of the KBD and its components. Data are represented as mean \pm SD $(n=3)$. Different letters in the same column are significantly different $(p<0.05)$.

\begin{tabular}{cccc}
\hline \multirow{2}{*}{ Samples } & ABTS Assay $^{\mathrm{a}}$ & DPPH Assay & AChE Assay $^{* *}$ \\
\cline { 2 - 4 } & $\mathbf{I C}_{\mathbf{5 0}} \mathbf{( \mathbf { m g } / \mathbf { m L } )}$ & $\left.\mathbf{I C}_{\mathbf{5 0}} \mathbf{( m g} / \mathbf{m L}\right)$ & IC $\left._{\mathbf{5 0}} \mathbf{( m g} / \mathbf{m L}\right)$ \\
\hline KBD & $0.90 \pm 0.06^{\mathrm{a}}$ & $0.62 \pm 0.06^{\mathrm{a}}$ & $2.17 \pm 0.23^{\mathrm{a}}$ \\
Nelumbo nucifera $(\mathrm{NN})$ & $0.56 \pm 0.03^{\mathrm{a}}$ & $0.26 \pm 0.00^{\mathrm{a}, \mathrm{b}}$ & $1.88 \pm 0.10^{\mathrm{a}}$ \\
Pipper nigrum $(\mathrm{BP})$ & $0.72 \pm 0.02^{\mathrm{a}}$ & $0.73 \pm 0.07^{\mathrm{a}, \mathrm{c}}$ & $0.93 \pm 0.12^{\mathrm{a}}$ \\
Centella asiatica $(\mathrm{CA})$ & $1.91 \pm 0.06^{\mathrm{a}}$ & $0.96 \pm 0.02^{\mathrm{a}, \mathrm{c}}$ & $>5^{\mathrm{b}}$ \\
Trolox $(\mu \mathrm{M})$ & $73.14 \pm 2.17$ & $22.91 \pm 0.16$ & - \\
Tacrine $(\mu \mathrm{M})$ & - & - & $0.29 \pm 0.03$ \\
\hline
\end{tabular}

* Data are expressed as $\mathrm{IC}_{50}$, the crude extract concentration that inhibits $50 \%$ of free radicals (mean $\left.\pm \mathrm{SD}\right) .{ }^{* *}$ Data are expressed as $\mathrm{IC}_{50}$, the crude extract concentration that inhibits $50 \%$ of AChE activity (mean $\pm \mathrm{SD}$ ).
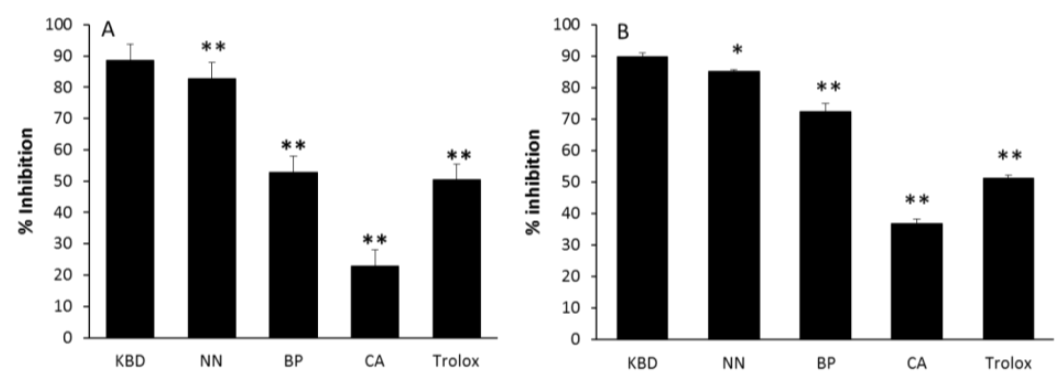

Figure 1. The effect of ethanol extracts of the KBD and its components on ABTS (A) and DPPH (B) radical scavenging action. The KBD extract of $3 \mathrm{mg} / \mathrm{mL}(\mathrm{KBD})$ and its components at equivalent amounts, i.e., Nelumbo nucifera $1 \mathrm{mg} / \mathrm{mL}$, (NN); Piper nigrum $1 \mathrm{mg} / \mathrm{mL}(\mathrm{BP})$, and Centella asiatica $1 \mathrm{mg} / \mathrm{mL}$ (CA), were evaluated for radical scavenging action by ABTS and DPPH assay. The values are reported as means $\pm \mathrm{SD}(n=5) .{ }^{*} p<0.05$ and ${ }^{* *} p<0.01$ as compared with the KBD group. Trolox at the concentration of 80 and $20 \mu \mathrm{M}$ was used as a positive control in ABTS and DPPH assay, respectively. 


\subsection{In Vitro Study of AChE Inhibitory Activity}

The KBD and its constituents were evaluated for their anti-acetylcholinesterase activity. The results are represented by $\mathrm{IC}_{50}$ values (Table 2). The $\mathrm{KBD}$ extract inhibited $\mathrm{AChE}$ with an $\mathrm{IC}_{50}$ value of $2.17 \pm 0.23 \mathrm{mg} / \mathrm{mL}$, whereas its components NN and BP inhibited 50\% of AChE function at concentrations of $1.88 \pm 0.10$ and $0.93 \pm 0.12 \mathrm{mg} / \mathrm{mL}$, respectively. CA showed no effect on AChE function at $5 \mathrm{mg} / \mathrm{mL}$. Tacrine, a reference standard, demonstrated AChE inhibitory activity with a $\mathrm{IC}_{50}$ value of $0.29 \pm 0.03 \mu \mathrm{M}$. By comparison among the components, the ethanol extract of BP displayed the most potent AChE inhibitory activity (Figure 2). The KBD at a concentration of $3 \mathrm{mg} / \mathrm{mL}$ inhibited AChE function (86.36 percentage inhibitory action), while its components $\mathrm{NN}, \mathrm{BP}$, and CA at $1 \mathrm{mg} / \mathrm{mL}$ showed varying abilities to inhibit $\mathrm{AChE}$ function with percentage inhibitory actions of $45.45 \%, 70.45 \%$, and $4.55 \%$, respectively. Our results suggest that $\mathrm{BP}$ and $\mathrm{NN}$ are the components mainly responsible for the anti-acetylcholinesterase activity of the KBD.

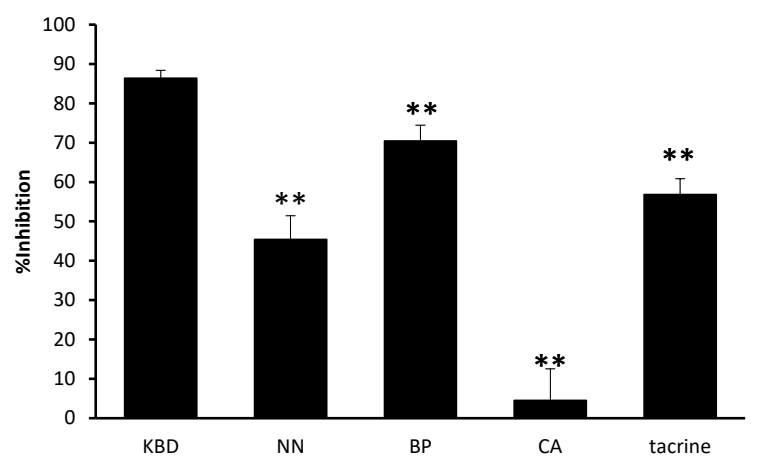

Figure 2. The effect of the KBD and its components on AChE activity. The KBD extract $3 \mathrm{mg} / \mathrm{mL}$ (KBD) and its components at equivalent amount, i.e., Nelumbo nucifera $1 \mathrm{mg} / \mathrm{mL}$, (NN), Piper nigrum $1 \mathrm{mg} / \mathrm{mL}$ (BP), and Centella asiatica $1 \mathrm{mg} / \mathrm{mL}(\mathrm{CA})$ were evaluated for AChE inhibitory action by Ellman's assay. Data are reported as means $\pm \mathrm{SD}(n=3) .{ }^{* *} p<0.01$ as compared with the KBD group. Tacrine $0.30 \mu \mathrm{M}$ was used as a positive control.

\subsection{In Vitro Assay for A Aggregation Inhibition}

The thioflavin $T$ assay revealed inhibition of amyloid $\beta$ aggregation by the KBD and its components, as shown in Figure 3. Curcumin $(10 \mu \mathrm{M})$ was used as a positive control. The KBD $(300 \mu \mathrm{g} / \mathrm{mL})$ and its components $(100 \mu \mathrm{g} / \mathrm{mL})$ inhibited $\mathrm{A} \beta_{1-42}$ aggregation with percentage inhibitory values ranging from $33.82-9.16 \%$.

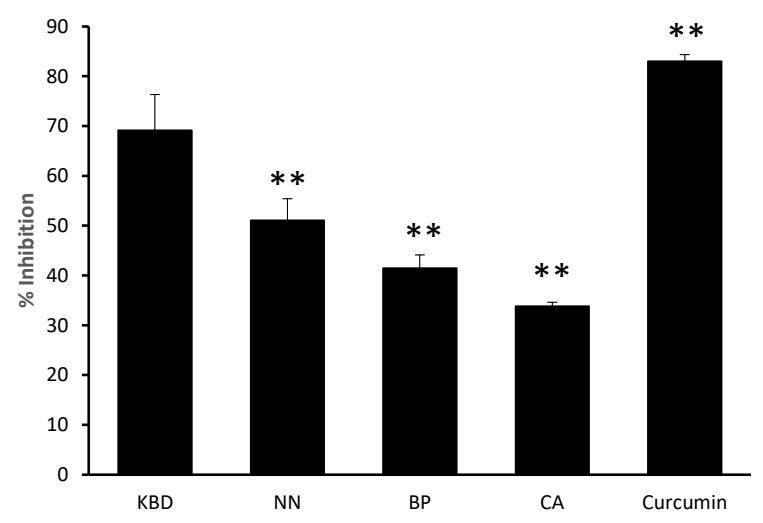

Figure 3. The effect of the KBD and its components on $\mathrm{A} \beta$ aggregation. The KBD extract $300 \mu \mathrm{g} / \mathrm{mL}$ (KBD) and its components at equivalent amounts, i.e., Nelumbo nucifera $100 \mu \mathrm{g} / \mathrm{mL}$ (NN), Piper nigrum $100 \mu \mathrm{g} / \mathrm{mL}$ (BP), and Centella asiatica $100 \mu \mathrm{g} / \mathrm{mL}$ (CA) were evaluated for inhibition of A $\beta_{1-42}$ aggregation by ThT assay. Curcumin $(10 \mu \mathrm{M})$ was used as a positive control. The values are reported as means \pm $\mathrm{SD}(n=3){ }^{* *} P<0.01$ as compared with the KBD group. 


\subsection{Effect on $\mathrm{H}_{2} \mathrm{O}_{2}$-Induced Cell Damage in Neuroblastoma Cells}

The neuroprotective effect of the KBD and its components (NN, BP, and CA) against oxidative stress was investigated by MTT assay in neuroblastoma cell line SH-SY5Y. To induce oxidative damage, hydrogen peroxide $\left(\mathrm{H}_{2} \mathrm{O}_{2}\right)$ was used and $\mathrm{N}$-acetyl cysteine (NAC) at $100 \mu \mathrm{g} / \mathrm{mL}$ was employed as a reference compound. Treatment of the neuronal cells with the KBD extract, at the concentration of $100 \mu \mathrm{g} / \mathrm{mL}$, significantly increased cell viability as compared with the $\mathrm{H}_{2} \mathrm{O}_{2}$ only control (Figure 4). For its components, tested at the equivalent amount $(35 \mu \mathrm{g} / \mathrm{mL})$, only NN showed a significant increase in cell viability as compared with the $\mathrm{H}_{2} \mathrm{O}_{2}$ only treated control (Figure 4).

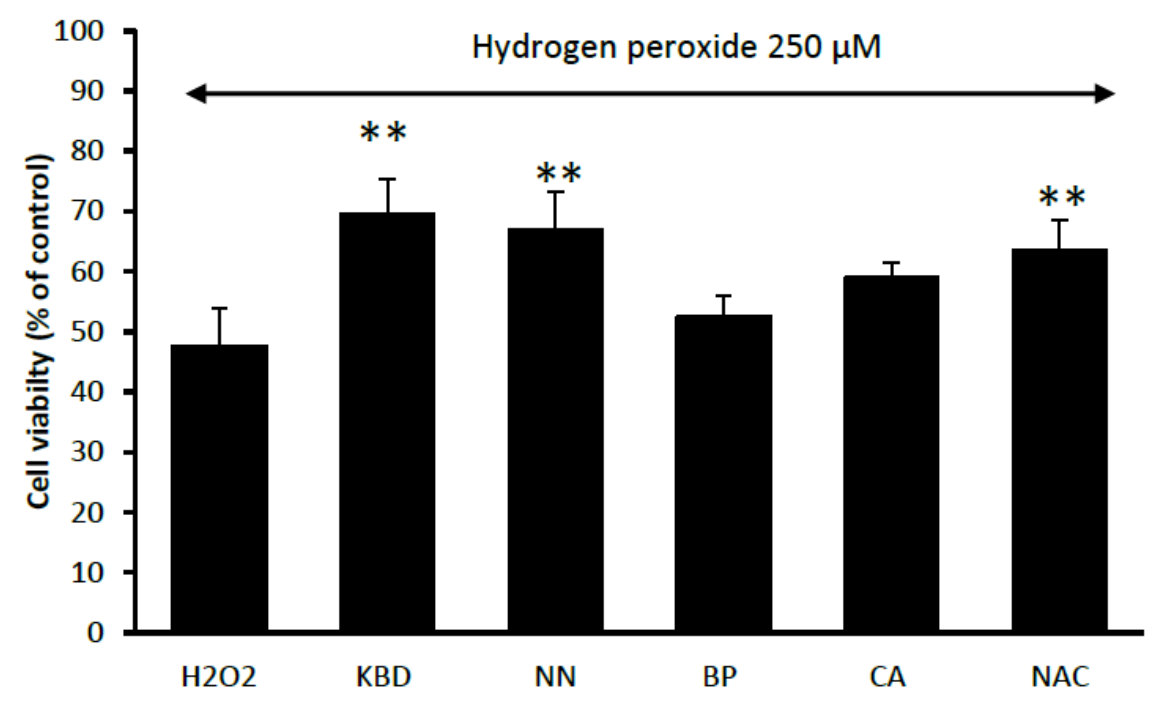

Figure 4. Effect of the KBD $100 \mu \mathrm{g} / \mathrm{mL}$ and its component extracts (Nelumbo nucifera (NN), Piper nigrum (BP), and Centella asiatica (CA) at $35 \mu \mathrm{g} / \mathrm{mL}$ on $\mathrm{H}_{2} \mathrm{O}_{2}$-induced oxidative cell damage in neuroblastoma cells. $N$-acetyl cysteine (NAC) at $100 \mu \mathrm{g} / \mathrm{mL}$ was used as a reference standard. Data are means $\pm \mathrm{SD}(n$ $=5) * * p 0.01$ as compared with the $\mathrm{H}_{2} \mathrm{O}_{2}$-treated control group.

\subsection{The Effect on the Expression of Proteins Related to Neuronal Cell Death}

To identify the protective mechanisms of the ethanol extracts of the KBD and its constituents against $\mathrm{H}_{2} \mathrm{O}_{2}$-induced cell damage, the effect of the extracts on the expression of pro- and antiapoptotic proteins in the SH-SY5Y neuroblastoma cell line was investigated using Western blot analysis (Figure 5). Treatment with $\mathrm{H}_{2} \mathrm{O}_{2}$ alone increased expression of the pro-apoptotic proteins (cleaved caspase-9, cleaved caspase-3, p-GSK3 $\beta$, p-P65, and p-JNK) and decreased expression of the anti-apoptotic proteins ( $\mathrm{MCl}_{1}$ and survivin). In comparison, treatment with KBD extract $(100 \mu \mathrm{g} / \mathrm{mL})$ downregulated expression of the following pro-apoptotic proteins: (i) cleaved caspase-9, (ii) cleaved caspase-3, (iii) p-GSK3 $\beta$, (iv) p-P65, and (v) p-JNK. Furthermore, treatment with the individual KBD components (NN, BP, and CA) at $35 \mu \mathrm{g} / \mathrm{mL}$ showed some effects on signaling protein expression. The $\mathrm{NN}$ extract inhibited JNK and p65 phosphorylation and cleavage of caspase- 9 and -3, while increasing levels of $\mathrm{MCl}_{1}$ and survivin. The BP extract also inhibited JNK and p65 phosphorylation while increasing $\mathrm{MCl}_{1}, \mathrm{BCL}_{\mathrm{xl}}$, and survivin expression but had no effect on caspase- 9 and -3 activation. For the CA extract, the cleavage of caspase- 9 and -3 , as well as phosphorylation of GSK3 $\beta$, P65, and JNK were all inhibited. However, expression of anti-apoptotic proteins $\mathrm{MCl}_{1}, \mathrm{BCL}_{\mathrm{xl}}$, and survivin was increased. Thus, the KBD neuroprotection was due to the combination of reduced expression of pro-apoptotic genes and increased expression of anti-apoptotic genes. 


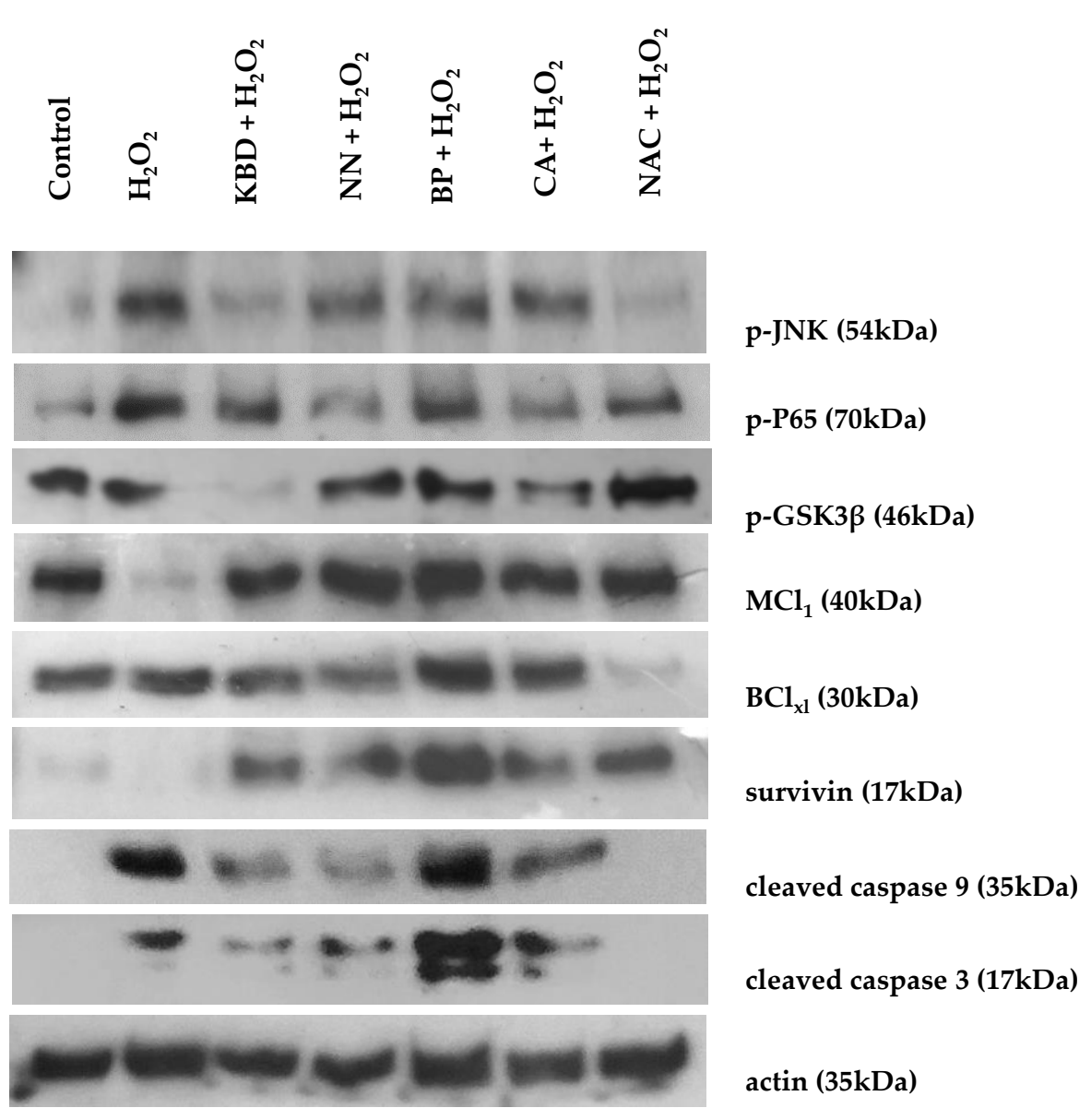

Figure 5. Effect of the KBD $(100 \mu \mathrm{g} / \mathrm{mL})$ and its components (Nelumbo nucifera (NN), Piper nigrum (BP), and Centella asiatica (CA), $35 \mu \mathrm{g} / \mathrm{mL}$ ) extracts on protein expression by Western blot analysis. The SH-SY5Y cells were treated with the KBD extract for $30 \mathrm{~min}$ by using $N$-acetyl cysteine (NAC) as a positive control, and then treated with $250 \mu \mathrm{M} \mathrm{H}_{2} \mathrm{O}_{2}$ for $10 \mathrm{~min}$. The cell lysate was prepared and signaling proteins were detected using antibodies against the following: (i) p-JNK, (ii) p-P65, (iii) $\mathrm{p}-\mathrm{GSK} 3 \beta$, (iv) $\mathrm{MCL}_{1}$, (v) $\mathrm{BCl}_{\mathrm{xl}}$, (vi) survivin, (vii) cleaved caspase-9, (viii) cleaved caspase-3, and (ix) actin.

\subsection{Behavioral Experiments}

\subsubsection{Morris Water Maze Test}

We examined the effects of the KBD on scopolamine-induced memory impairment in ICR mice using the Morris water maze and the Y-maze tasks.

Assessment of the effect of the KBD on scopolamine-induced memory impairment was conducted after the mice had been treated with KBD for seven days. The water maze results showed that the mice in the control group spent more time in the target quadrant (Q1) than those in the scopolamine-treated group (Figure 6). The result indicated that the scopolamine-treated mice were in an amnesic state. Tacrine $(10 \mathrm{mg} / \mathrm{kg})$, as a positive control, significantly improved cognitive deficits indicated by the mice spending more time in the target quadrant than the amnesic mice. Mice treated with the KBD at the dose of 100 and $500 \mu \mathrm{g} / \mathrm{mL}$ also spent significantly more time in the target quadrant than the scopolamine-treated group. The result indicated that the KBD could improve long-term memory in mice with amnesia induced by scopolamine. 


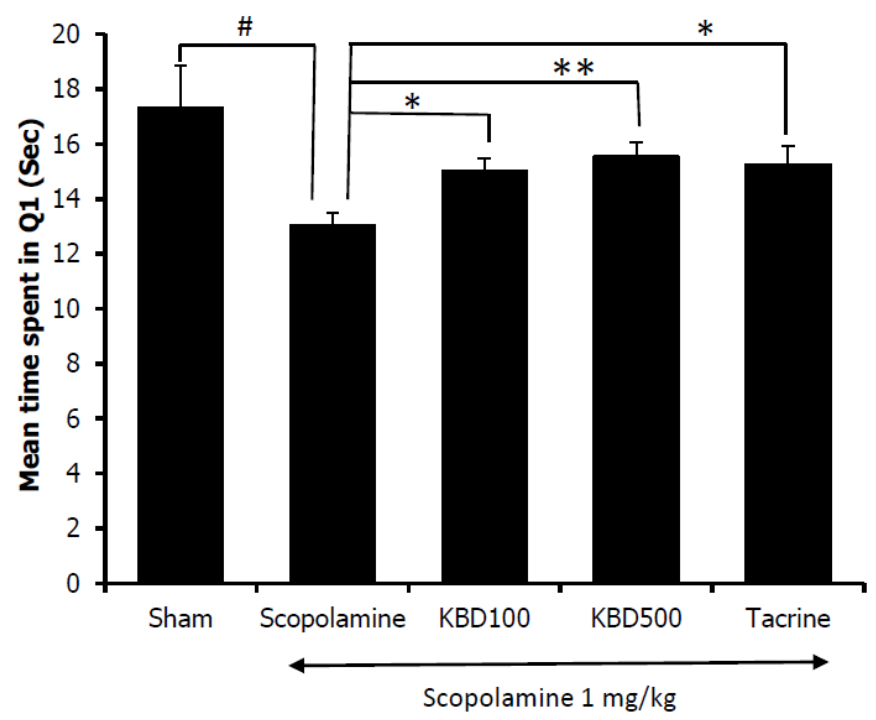

Figure 6. Effect of the KBD (100 and $500 \mathrm{mg} / \mathrm{kg}$ ) on memory impairment induced by scopolamine in the water maze test. Tacrine at the dose of $10 \mathrm{mg} / \mathrm{kg} / \mathrm{day}$ was used as a reference standard. The data were shown as mean \pm SEM $(n=8-10) .{ }^{*} p<0.05$ versus control group (Sham), ${ }^{*} p<0.05$ and ${ }^{* *} p<0.01$ versus scopolamine-treated group.

\subsubsection{Y-Maze Test}

Spontaneous alteration behavior in the Y-maze test is considered to correlate with immediate spatial working memory, a form of short-term memory [16]. The percentage of alternation behavior was measured after seven days of KBD treatment. As shown in Figure 7, the results showed that the mice in the scopolamine-treated group had a reduced alternation percentage as compared with the control group $(p<0.01)$, and the reduced alternation induced by scopolamine was significantly reversed by the KBD at $500 \mathrm{mg} / \mathrm{kg} /$ day $(p<0.05)$.

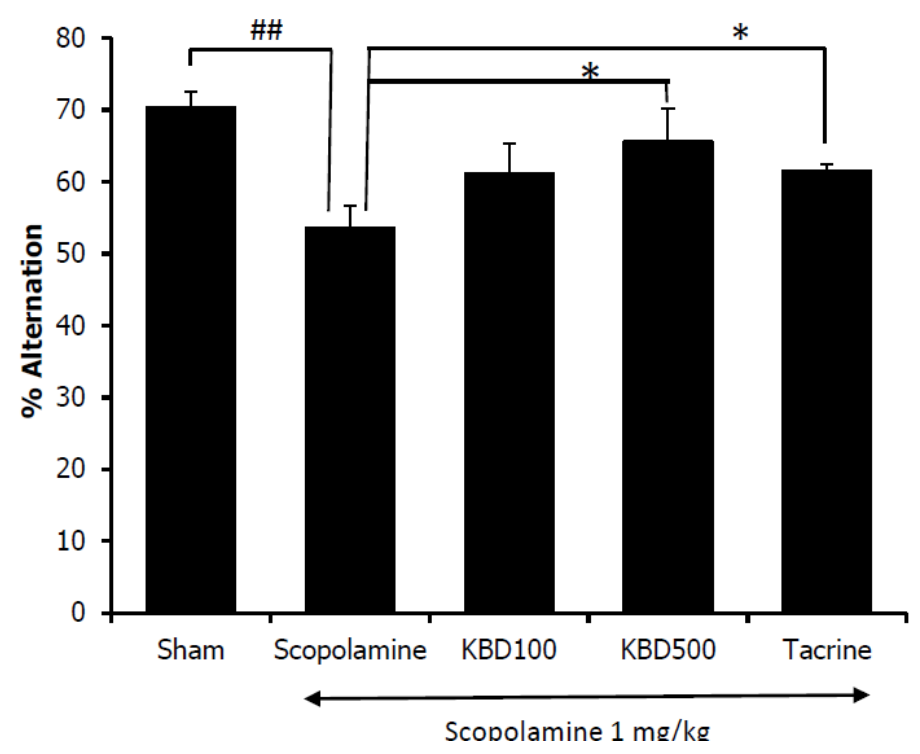

Figure 7. Effect of the KBD (100 and $500 \mathrm{mg} / \mathrm{kg}$ ) on memory impairment induced by scopolamine in Y-maze test. Tacrine at the dose of $10 \mathrm{mg} / \mathrm{kg} /$ day was used as a reference standard. The data were shown as mean $\pm \operatorname{SEM}(n=8-10)$. ${ }^{\# \#} p<0.01$ versus control group (Sham), ${ }^{*} p<0.05$ versus scopolamine-treated group. 


\section{Discussion}

Due to the multifaceted pathogenesis of $\mathrm{AD}$, the agents targeting at multiple stages of the pathogenic cascade seem to constitute a potential drug for $\mathrm{AD}$ treatment. Compounds from natural plants, the latter a rich source of chemical diversity, can create a potential multitarget drug for disease treatment. The KBD consists of three herbal plants relevant to $\mathrm{AD}$ treatment; thus, the KBD can have good potential for the treatment of AD. Hence, this study was conducted to investigate the potential of the KBD for AD treatment.

Oxidative stress has been widely associated in the development and progression of neuronal cell death which, in turn, leads to neurodegenerative disorders including cognitive decline in AD. Oxidative stress reflects an imbalance between the generation of free radicals and an individual's antioxidative defense system [31]. Hence, antioxidant drugs can counteract the neurotoxic and harmful effects of oxidative stress and alleviate the progress of AD. Several studies have shown that treatment with antioxidants could delay the development of $\mathrm{AD}[32,33]$. In the present study, the in vitro antioxidant activity of the KBD and its components correlated with the total phenolic content of crude extracts. This is consistent with a previous study that reported strong correlations between total phenol content and radical scavenging activity [34]. The radical scavenging activity of the KBD is likely to be provided by NN, which has the highest phenolic content.

It has long been recognized that the cholinergic system plays a vital role in a number of cognitive functions [35]. Evidence has suggested that memory deficit in AD results from a decline of acetylcholine $(\mathrm{ACh})$, which is the neurotransmitter that plays roles in learning and memory functions [36]. Hydrolysis of ACh through AChE results in termination of cholinergic transmission, therefore, inhibition of AChE serves as a therapeutic target for $\mathrm{AD}$ treatment. This research has demonstrated that the KBD extract showed an AChE inhibitory effect in a dose-dependent manner. Furthermore, the AChE inhibitory activity of the KBD mainly comes from BP, which has a high flavonoid content. This outcome correlates with a previous study showing that several flavonoids possess AChE inhibitory activity [37].

Another key neuropathological hallmark of $\mathrm{AD}$ is the accumulation of toxic $\mathrm{A} \beta$ plaques in the brain. Therefore, halting the pathological $A \beta$ aggregation is the principal goal of several therapeutic strategies in preclinical development or in clinical trials. $A \beta_{1-42}$ is a main composition of amyloid plaques evident in the $A D$ brain and several studies have indicated that $A \beta_{1-42}$ is an important factor in the etiology of $A D[38,39]$. In vitro and transgenic mice studies have shown that $A \beta_{1-42}$ aggregates to form amyloid plaques faster than $A \beta_{1-40}$. Therefore, we employed $A \beta_{1-42}$ to examine $A \beta$ aggregation. The KBD extract, NN, BP, and CA all inhibited the aggregation of $A \beta_{1-42}$ in the in vitro assay. In addition, the $A \beta$ aggregation inhibition activity had a good correlation with phenolic content. Thus, it appears the $A \beta$ aggregation inhibitory activity of the KBD extract mainly comes from NN.

Reactive oxygen species (ROS) possess the ability to damage neuronal cell via apoptosis or necrosis. An exogenous source of ROS, such as $\mathrm{H}_{2} \mathrm{O}_{2}$, is widely used to cause apoptosis (mild oxidative stress) and necrosis (severe oxidative stress) [40]. Several instances revealed etiological associations between the production of $\mathrm{H}_{2} \mathrm{O}_{2}$ and neurodegenerative diseases [41]. Thus, $\mathrm{H}_{2} \mathrm{O}_{2}$-induced neuronal damage is considered to be a suitable model for the study of neurodegeneration induced by oxidative stress [42]. Pretreatment of SH-SY5Y cells with the KBD significantly increased the viability of cells exposed to $\mathrm{H}_{2} \mathrm{O}_{2}$. Of the individual components, only NN showed any improvement in cell viability as compared with the $\mathrm{H}_{2} \mathrm{O}_{2}$ treated control. This neuroprotective action of the KBD can partly come from the antioxidant activity of the extract. However, the neuroprotective ability of its components was not related to antioxidant activity. Our results indicate that BP, which has a higher antioxidant capacity than CA, showed a less neuroprotective effect. Apart from the antioxidant action, the protective effect could come from other mechanisms. Therefore, to identify the protective mechanisms of the ethanol extracts of the KBD and its constituents against $\mathrm{H}_{2} \mathrm{O}_{2}$-induced cell death, we investigated the effect of the KBD and its components on the expression of pro- and anti-apoptotic proteins using Western blot analysis. Pretreatment of SH-SY5Y cells with the KBD extract or its components (NN, BP, and CA) prior to $\mathrm{H}_{2} \mathrm{O}_{2}$ exposure showed downregulation of the following pro-apoptotic proteins: (i) 
cleaved caspase-9, (ii) cleaved caspase-3, (iii) GSK-3 $\beta$, (iv) p-P65, and (v) p-JNK and upregulation of the following anti-apoptotic proteins: (i) $\mathrm{MCl}_{1}$, (ii) $\mathrm{Bcl}_{\mathrm{xl}}$, and (iii) survivin. Previous studies have reported that oxidative stress-induced neuronal cell death in $\mathrm{H}_{2} \mathrm{O}_{2}$-induced SH-SY5Y cells is associated with the mitochondrial apoptotic pathway and is an important mechanism in neurodegenerative diseases. The excessive ROS generation causes the increase of mitochondrial membrane permeability, resulting in the release of cytochrome C. Released cytochrome C activates pro-apoptotic factors, such as caspase- 9 and -3 , and eventually induces cell death. Our results show increased proteolytic cleavage of caspase- 9 and -3 , and increased phosphorylation of p-GSK-3 $\beta$, p-P65, and p-JNK following treatment with $\mathrm{H}_{2} \mathrm{O}_{2}$. The KBD protects neuronal cells against $\mathrm{H}_{2} \mathrm{O}_{2}$-induced death by downregulation of cleaved caspase- 9 and cleaved caspase-3, decreased phosphorylation of GSK-3 $\beta$, P65, and JNK, as well as increased expression of $\mathrm{MCl}_{1}, \mathrm{Bcl}_{\mathrm{xl}}$, and survivin. Therefore, the KBD appears to protect against neuronal cell death induced by oxidative stress through both its antioxidant and anti-apoptosis actions.

Taken together, the in vitro results indicate that the KBD possesses multimodes of action against multiple targets in the AD pathological cascade including: (a) antioxidant, (b) anti-AChE, (c) anti-A $\beta$ aggregation, (d) neuroprotection, and (e) anti-apoptosis. These activities resulted from different phytochemical contents and from different plants that comprise the KBD. Due to the multifaceted pathogenesis nature of $\mathrm{AD}$, various classical agents were proved to be ineffective because they were mostly designed to cope with only one mode of action. Thus, the KBD which demonstrated multimode of actions is more likely to possess higher potential for AD treatment. Our data also proved that the KBD revealed additional benefits as compared with the activities of its individual plant in the composition. The KBD demonstrated a broader mode of action against AD as compared with its individual plant formulation. Due to a lower dose of each component, the KBD could generate less toxicity for a long-term treatment of AD.

Furthermore, we examined the effect of the KBD on memory deficit induced by scopolamine in mice. The nonselective muscarinic antagonist scopolamine has frequently been used to impair learning and memory. Scopolamine-induced amnesia is the classical approach to evaluate the effects of novel cognition-enhancing drugs in animals [43].

The Morris water maze was employed to assess the long-term memory of the experimental animals [44]. On testing day, if the mice spent more time in the target quadrant where the platform had previously been located during the training trials, this outcome would indicate spatial memory improvement [35]. In contrast, the Y-maze investigated working memory or short-term memory by observing the animal's spontaneous alternation behavior. Mice with short-term memory loss could not recall which arm they had just visited, and thus showed reduced spontaneous alternation. Our results showed that the seven-day KBD treatment reversed scopolamine-induced memory deficit. The treated mice demonstrated increased spontaneous alternation in the Y-maze test and increased the time spent in the quadrant where the platform had previously been placed in the water maze test. Our in vivo results indicated that the KBD could improve both short-term and long-term memories in amnesic mice whose memory loss was induced by scopolamine. Several studies have indicated that scopolamine impaired the cholinergic system's performance by acting on muscarinic receptors and increasing AChE activity. From our in vitro AChE function assay, the KBD demonstrated AChE inhibitory action. Tacrine also works by inhibiting AChE. Both KBD and tacrine showed improvement in memory deficit induced by scopolamine, which suggests that they act via a similar mechanism. Moreover, a previous study reported that $\mathrm{NN}$, one of the components of the KBD, reversed scopolamine induced memory impairment by increasing ChAT expression [23]. Therefore, the cognitive improvement resulting from treatment by the KBD could partly come from the AChE inhibitory action, coupled with stimulation of ChAT expression. 


\section{Materials and Methods}

\subsection{Chemicals and Reagents}

The KBD and its three components as follows: (i) Nelumbo nucifera petals (NN), (ii) Piper nigrum fruits (BP), and (iii) the aerial part of Centella asiatica (CA) were provided by Chao Phya Abhaibhubejhr Hospital, Prachinburi Province, Thailand. The plants were identified by Benjawan Leenin, a chief of Traditional Knowledge Center, Chao Phya Abhaibhubejhr Hospital Foundation. The relative herbarium voucher specimens were deposited at the museum of Chao Phya Abhaibhubejhr Hospital with following voucher numbers: $\mathrm{ABH} 15, \mathrm{ABH} 18$, and $\mathrm{ABH} 17$, respectively. Acetylthiocholine iodide (ATCI), bovine serum albumin (BSA), beta amyloid 1-42 (A $\left.\beta_{1-42}\right)$, gallic acid, quercetin, $\beta$ carotenoid, tacrine, trolox, $N$-acetyl cysteine (NAC), trypsine, fetal bovine serum (FBS), and Dulbecco's modified Eagle medium nutrient mixture F-12 (DMEM/F12) were purchased from Sigma-Aldrich (SM Chemical supplies Co., Ltd., Bangkok, Thailand), Merck (Merck, Bangkok, Thailand), Gibthai (GT Chemical supplies Co., Ltd., bangkok, Thailand), and Fluka (SM Chemical supplies Co., Ltd. ,Bangkok, Thailand).

\subsection{Preparation of KBD and Its Components Extracts}

Crude extracts of KBD, NN, BP, and CA were prepared by macerating with ethanol at 1:5 (w/v) ratios for 3 days and repeated twice. Concentrated extracts were obtained by filtration, and then evaporation using a rotary evaporator. The concentrated extracts were lyophilized into powder and stored in air-tight containers at $2-8{ }^{\circ} \mathrm{C}$ until needed for use. The yields of the crude extracts were KBD $(11.32 \%), \mathrm{NN}(5.26 \%), \mathrm{BP}(6.40 \%)$, and CA $(5.90 \%)$ of dry weight. The HPLC analysis of the KBD extract has been reported in a previous study [20]. Before using, the extract powder was prepared as stock solution in ethanol or DMSO with the concentration of $10 \mathrm{mg} / \mathrm{mL}$.

\subsection{Assessment of Total Phenolic and Total Flavonoid Contents}

The total phenolic content was determined by dissolving KBD, NN, BP, and CA crude extracts in ethanol, and then $10 \mu \mathrm{L}$ of each extract was combined with $75 \mu \mathrm{L}$ of Folin-Ciocalteu reagent. The ingredients were mixed and left for $5 \mathrm{~min}$, prior to the addition of $75 \mu \mathrm{L}$ of $7.5 \%$ sodium carbonate solution. After $2 \mathrm{~h}$ of incubation, absorption at wavelength $700 \mathrm{~nm}$ was measured. The total phenolic content of each extract is shown as $\mu \mathrm{g}$ of gallic acid equivalents per mg of crude extract ( $\mu \mathrm{g}$ GAE/mg CE) against a calibration curve with gallic acid. All samples were analyzed in three replicates [45].

The total flavonoid content assay was performed by adding the following: (i) $20 \mu \mathrm{L}$ of sample, (ii) $15 \mu \mathrm{L}$ of aluminum chloride solution (2.5\%), (iii) $20 \mu \mathrm{L}$ of sodium acetate $(100 \mathrm{~g} / \mathrm{L})$, and (iv) $145 \mu \mathrm{L}$ of distilled water, into 96-well plates. The mixture was left at room temperature for $15 \mathrm{~min}$ and absorbance was detected at a wavelength of $450 \mathrm{~nm}$. Quercetin was used as a reference standard. The total flavonoid content is shown as $\mu \mathrm{g}$ of quercetin equivalents per mg of crude extract $(\mu \mathrm{g} \mathrm{QE} / \mathrm{mg}$ CE) against the calibration curve of quercetin [46].

\subsection{In Vitro Antioxidant Activities Assays}

The antioxidant activities of ethanol extracts of KBD, NN, BP, and CA were investigated by the following two methods: (i) ABTS (2,2'-azino-bis-3-ethylbenzthiazoline-6-sulphonic acid) and (ii) DPPH (1,1-diphenyl-2-picrylhydrazyl).

The $\mathrm{ABTS}^{\bullet+}$ mixture was prepared by incubating $7 \mathrm{mM}$ ABTS with $2.45 \mathrm{mM}$ potassium persulfate for $16 \mathrm{~h}$ in the dark. Ethanol was added to the $\mathrm{ABTS}^{\bullet+}$ solution to achieve absorbance of $0.80 \pm 0.02$ at $700 \mathrm{~nm}$. Then, $50 \mu \mathrm{L}$ of various concentration of crude extracts in ethanol were mixed with $100 \mu \mathrm{L}$ of the $\mathrm{ABTS}^{\bullet+}$ mixture. The absorbance at $700 \mathrm{~nm}$ was determined $15 \mathrm{~min}$ after initial mixing [16]. Trolox served as a positive control. 
The DPPH assay was carried out by incubating $100 \mu \mathrm{L}$ of various concentrations of crude extracts in ethanol with $100 \mu \mathrm{L}$ of $0.2 \mathrm{mM}$ DPPH solution for $30 \mathrm{~min}$. The absorbance was determined at $550 \mathrm{~nm}$ using a microplate reader [47]. The ability to scavenge free radicals was calculated using this equation:

$$
\text { Percentage inhibition }=\left(A_{C}-A_{S}\right) / A_{C} \times 100
$$

where $A_{C}$ is absorbance of control and $A_{S}$ is absorbance of the sample.

\subsection{In Vitro AChE Inhibitory Activity Assay}

The AChE inhibitory activities of ethanol extracts of KBD, NN, BP, and CA were investigated by using the modified Ellman's method [48]. The assay was conducted with microplates in triplicate by mixing the following: (a) $25 \mu \mathrm{L}$ of $1 \mathrm{mM}$ ATCI, (b) $25 \mu \mathrm{L}$ of $0.1 \mathrm{M}$ phosphate buffer, (c) $25 \mu \mathrm{L}$ of the extracts, and (d) $125 \mu \mathrm{L}$ of $1 \mathrm{mM}$ DTNB with $50 \mu \mathrm{L}$ of AChE from an electric eel type VI-S (0.2 Units/mL). At least 5 concentrations of extracts were determined. The absorbance at $405 \mathrm{~nm}$ was monitored once every $30 \mathrm{~s}$ for $5 \mathrm{~min}$. The enzymatic activity and percentage inhibition were determined. The inhibitory activity can be calculated from enzymatic activity by the following equation:

$$
\text { Percentage inhibition }=\left[\left(\mathrm{A}_{E}-\mathrm{A}_{\mathrm{S}}\right) /\left(\mathrm{A}_{\mathrm{E}}-\mathrm{A}_{\mathrm{C}}\right)\right] \times 100
$$

where $A_{E}, A_{S}$, and $A_{C}$ are the enzymatic activity of enzyme, sample, and control, respectively.

\subsection{In Vitro Assay for A $\beta$ Aggregation Inhibition}

A thioflavin-T (ThT) fluorescence assay was operated to monitor the aggregation of amyloid $\beta$ (A $\beta 1-42$ ) [49]. Curcumin at the concentration of $10 \mu \mathrm{M}$ was used as a reference standard. Briefly, $25 \mu \mathrm{M}$ of $\mathrm{A} \beta 1-42$ in $50 \mathrm{mM}$ phosphate buffer $\mathrm{pH} 7.4$ was incubated with $\mathrm{KBD}(300 \mu \mathrm{g} / \mathrm{mL}), \mathrm{NN}$, $\mathrm{BP}$, or CA $(100 \mu \mathrm{g} / \mathrm{mL})$, or curcumin $(10 \mu \mathrm{M})$ for $48 \mathrm{~h}$ at $37^{\circ} \mathrm{C}$. After incubation, the mixtures were combined with $5 \mu \mathrm{M}$ ThT in glycine/ $\mathrm{NaOH}$ buffer $\mathrm{pH}$ 8.0. Fluorescence intensity was measured with excitation/emission wavelengths of $446 / 490 \mathrm{~nm}$. The percentage inhibition of aggregation was obtained by using the following equation:

$$
\text { Percentage inhibition }=(1-\mathrm{IFs} / \mathrm{IFc}) \times 100 \%
$$

where IFs and IFc were the fluorescence intensities of sample and control, respectively.

\subsection{Effect on Hydrogen Peroxide-Induced Cell Damage in Neuroblastoma Cells}

Neuroblastoma cells (SH-SY5Y) were maintained in DMEM/F12 containing $10 \%$ FBS at $37^{\circ} \mathrm{C}$ in a humidified $5 \% \mathrm{CO}_{2}$ incubator. Then, cells were plated at a density of $2.5 \times 10^{5}$ cell/mL into a 96 -well plate for all experiments. The cells were pretreated with $100 \mu \mathrm{g} / \mathrm{mL} \mathrm{KBD,} \mathrm{its} \mathrm{components} \mathrm{NN,} \mathrm{BP,} \mathrm{or} \mathrm{CA}$ at equivalent amounts $(35 \mu \mathrm{g} / \mathrm{mL})$ or standard reference NAC $(100 \mu \mathrm{g})$ for $2 \mathrm{~h}$, and then incubated with or without hydrogen peroxide $\left(\mathrm{H}_{2} \mathrm{O}_{2}\right)$ at a concentration of $250 \mu \mathrm{M}$ for $2 \mathrm{~h}[15,16]$. Cell viability was detected by staining the cells with 3-(4,5-dimethyl-2-thiazolyl)-2,5-diphenyl-2H-tetrazolium bromide (MTT) $(5 \mathrm{mg} / \mathrm{mL}$ in PBS) for $2 \mathrm{~h}$. The absorbance was recorded by a well plate reader at $600 \mathrm{~nm}$. All data were represented as percentages of non- $\mathrm{H}_{2} \mathrm{O}_{2}$-treated groups (control group). The cell viability of control group was expressed as $100 \%$.

\subsection{Effect on Protein Expression Induced by $\mathrm{H}_{2} \mathrm{O}_{2}$ in Neuroblastoma Cells}

The SH-SY5Y cells were maintained in DMEM/F12 containing $10 \%$ FBS at $37^{\circ} \mathrm{C}$ in a humidified $5 \% \mathrm{CO}_{2}$ incubator. Cells at a density of $1 \times 10^{6}$ cell $/ \mathrm{mL}$ were plated into a 6-well plate. The cells were pretreated with $100 \mu \mathrm{g} / \mathrm{mL} \mathrm{KBD}$, its components NN, BP, or CA at equivalent amounts $(35 \mu \mathrm{g} / \mathrm{mL}) \mathrm{or}$ the standard reference NAC $(100 \mu \mathrm{g})$ for $30 \mathrm{~min}$. After washing the unabsorbed substances, the cells were treated with $\mathrm{H}_{2} \mathrm{O}_{2} 250 \mu \mathrm{M}$ for $15 \mathrm{~min}$. Then, to lyse cells, the treated cells were mixed with 
an ice-cold lysis buffer for $30 \mathrm{~min}$. The lysate was centrifuged at $13,500 \mathrm{rpm}$ for $10 \mathrm{~min}$ at $4{ }^{\circ} \mathrm{C}$ and the supernatant was taken. The total protein concentration was quantified by using the Bradford assay. Proteins were separated using SDS-PAGE and transferred to a polyvinylidene difluoride (PVDF) membrane. The membrane was treated with BlockAce and probed with primary antibodies (cleaved caspase-9, cleaved caspase-3, p-GSK-3 $\beta$, p-P65, and p-JNK, as well as the anti-apoptotic proteins $\mathrm{MCl}_{1}, \mathrm{Bcl}_{\mathrm{xl}}$, and survivin). The antibodies were monitored using horseradish peroxidase-conjugated anti-rabbit, or anti-goat secondary antibodies and visualized with the enhanced chemiluminescence system [50].

\subsection{The Effects of KBD on Scopolamine-Induced Memory Impairments in Mice}

The study was conducted on male ICR mice weighing between 25 and $35 \mathrm{~g}$, derived from the National Laboratory Animal Centre, Nakorn Pathom, Thailand. All animal studies were approved by the Institutional Animal Care and Use Committee of Khon Kaen University, Thailand (record no. IAC UC-KKU-25/62). The mice were kept in groups of five per cage for seven days in the animal house, at an ambient temperature of $25^{\circ} \mathrm{C}$ with humidity level of $50-55 \%$ and a $12 \mathrm{~h}$ diurnal light cycle, prior to testing. Water and food were freely available in their home cages.

The effect of KBD on scopolamine-induced memory deficit in mice was investigated using two behavioral models, i.e., water maze and Y-maze tests. After treatment with the KBD powder (100 and $500 \mathrm{mg} / \mathrm{kg} /$ day, oral (p.o.) administration) or a reference standard $(10 \mathrm{mg} / \mathrm{kg} /$ day of tacrine, p.o.) for seven days, male ICR mice were examined for behavioral changes in learning and memory. The KBD dose was calculated from the clinical dose (2000 mg/day), which was prescribed in the hospital [20]. This dose was converted into the appropriate dose for mice, according to the following equation: human equivalent dose $(\mathrm{HED}, \mathrm{mg} / \mathrm{kg})=$ mouse dose $(\mathrm{mg} / \mathrm{kg}) \times($ mouse $\mathrm{Km} / \mathrm{Human} \mathrm{Km})$, where $\mathrm{Km}$ is the correction factor [51]. For each experiment, after treatment with test compounds for $1 \mathrm{~h}$, the memory deficit was induced by scopolamine. Thirty minutes after scopolamine administration, all animals were evaluated for memory deficit by Morris water maze and Y-maze tests.

The Morris water maze [44] was composed of a black circular pool $(70 \mathrm{~cm}$ in diameter and $28 \mathrm{~cm}$ high) filled with water $\left(25 \pm 1^{\circ} \mathrm{C}\right)$ and a dark removable platform $(6 \times 10 \times 15 \mathrm{~cm})$ placed $1 \mathrm{~cm}$ beneath water surface in a targeted quadrant $(\mathrm{Q} 1)$. For the training session, the mice were introduced into various quadrants of the pool (Q1-Q4) and allowed to swim for $60 \mathrm{~s}$ in search of the platform. The time spent to reach the platform was recorded as "escape latency". Each animal was subjected to four trials per day for 5 consecutive days. For the test session, the mice were released in the water pool without platform and allowed to swim from the various quadrants for $60 \mathrm{~s}$. The swimming time was recorded in the target quadrant (Q1) where the platform had been placed.

For the Y-maze test [16], the Y-maze apparatus was made of black polypropylene with three equally spaced arms at a $120^{\circ}$ angle from each other. Each arm was $40 \mathrm{~cm}$ long, $10 \mathrm{~cm}$ wide at the top, $3 \mathrm{~cm}$ wide at the bottom, and $12 \mathrm{~cm}$ high. Each mouse was positioned at the end of one arm and allowed to move freely through the maze for $8 \mathrm{~min}$. The total number of arm entries and the sequence of entries were manually recorded in order to calculate the percentage of alternation. The alternation behavior was classified by consecutive visits into all three arms without repeated entries. The alternation was represented as the ratio of alternation to possible alternation multiplied by 100 .

\subsection{Statistical Analyses}

The results are represented as mean $\pm \operatorname{SD}(n=4-6)$ and mean \pm SEM $(n=8-10)$ for in vitro and in vivo experiments, respectively. Statistical significance was determined by student $\mathrm{t}$-test or one-way analysis of variance (ANOVA). For all statistical analysis, significance levels were set at a $p$ value $<0.05$. 


\section{Conclusions}

The results from the present study indicate that the KBD possesses multiple modes of action aiming at multiple targets in the AD pathology cascade which include: (i) AChE inhibition, (ii) free radical scavenging action, (iii) anti-amyloid $\beta$ aggregation, and (iv) neuroprotection against $\mathrm{H}_{2} \mathrm{O}_{2}$ induced damage. The KBD reduced $\mathrm{H}_{2} \mathrm{O}_{2}$-induced neuronal cell death by inhibiting pro-apoptotic factors, specifically the following: (a) blocking caspase- 9 and (b) caspase- 3 cleavage activation, (c) changing phosphorylation levels of P65, (d) JNK, and (e) GSK-3 $\beta$, while activating the following anti-apoptotic factors: (a) $\mathrm{MCl}_{1}$, (b) $\mathrm{BCl}_{\mathrm{xl}}$, and (c) survivin. Furthermore, the KBD exhibited an ability to improve scopolamine induced memory deficit in mice. Our results illustrate that the Kleeb Bua Daeng formula has the potential to be employed in AD treatment. Thus, the Kleeb Bua Daeng formula could be used as an alternative novel choice for the prevention and treatment of patients with Alzheimer's disease.

Author Contributions: Conceptualization, C.B., P.W., S.P., Y.C., S.D., O.M., N.M., and P.K.; methodology, P.W. and C.B.; formal analysis, C.C., C.B., and P.W.; investigation, C.C., K.P., P.W., and C.B; resources, C.B. and S.P.; writing-original draft preparation, C.C. and C.B.; writing-review and editing, C.B. and P.W.; project administration, C.B. All authors have read and agreed to the published version of the manuscript.

Funding: This work was supported by the Khon Kaen University (I62-00-21-03, I62-00-21-02), the Thailand Research Fund (BDG6080006), the Royal Scholarship under Her Royal Highness Princess Maha Chakri Sirindhorn Education Project to the Kingdom of Cambodia, the Thailand Center of Excellence for Life Sciences (Public Organization), the Faculty of Pharmaceutical Sciences and Research Transfer Affairs, Khon Kaen University, Thailand.

Acknowledgments: The authors would like to thank Glenn Borlace, Faculty of Pharmaceutical Sciences, Khon Kaen University, Thailand for providing English language assistance.

Conflicts of Interest: The authors declare no conflict of interest.

\section{References}

1. Habtemariam, S. Natural Products in Alzheimer's Disease Therapy: Would Old Therapeutic Approaches Fix the Broken Promise of Modern Medicines? Molecules 2019, 24, 1519. [CrossRef] [PubMed]

2. World Alzheimer Report 2018-The state of the art of dementia research: New frontiers. Available online: https://www.alz.co.uk/research/world-report-2018 (accessed on 24 April 2020).

3. Wimo, A.; Guerchet, M.; Ali, G.-C.; Wu, Y.-T.; Prina, A.M.; Winblad, B.; Jönsson, L.; Liu, Z.; Prince, M. The worldwide costs of dementia 2015 and comparisons with 2010. Alzheimers Dement. 2017, 13, 1-7. [CrossRef] [PubMed]

4. Green, K.; Fosso, M.; Garneau-Tsodikova, S. Multifunctional Donepezil Analogues as Cholinesterase and BACE1 Inhibitors. Molecules 2018, 23, 3252. [CrossRef] [PubMed]

5. Pepeu, G.; Grazia Giovannini, M. The fate of the brain cholinergic neurons in neurodegenerative diseases. Brain Res. 2017, 1670, 173-184. [CrossRef]

6. Vetrivel, K.S.; Thinakaran, G. Amyloidogenic processing of beta-amyloid precursor protein in intracellular compartments. Neurology 2006, 66, S69-S73. [CrossRef]

7. Guo, J.-P.; Arai, T.; Miklossy, J.; McGeer, P.L. A $\beta$ and tau form soluble complexes that may promote self aggregation of both into the insoluble forms observed in Alzheimer's disease. Proc. Natl. Acad. Sci. USA 2006, 103, 1953-1958. [CrossRef]

8. King, M.E.; Kan, H.-M.; Baas, P.W.; Erisir, A.; Glabe, C.G.; Bloom, G.S. Tau-dependent microtubule disassembly initiated by prefibrillar $\beta$-amyloid. J. Cell Biol. 2006, 175, 541-546. [CrossRef]

9. Praticò, D.; Sung, S. Lipid Peroxidation and Oxidative imbalance: Early functional events in Alzheimer's disease. J. Alzheimers Dis. 2004, 6, 171-175. [CrossRef]

10. Zhu, X.; Su, B.; Wang, X.; Smith, M.A.; Perry, G. Causes of oxidative stress in Alzheimer disease. Cell. Mol. Life Sci. 2007, 64, 2202-2210. [CrossRef]

11. Castro, A.; Conde, S.; Rodriguez-Franco, M.; Martinez, A. Non-Cholinergic Pharmacotherapy Approaches to the Future Treatment of Alzheimers Disease. Mini-Rev. Med. Chem. 2002, 2, 37-50. [CrossRef]

12. Wilkinson, D.G.; Francis, P.T.; Schwam, E.; Payne-Parrish, J. Cholinesterase Inhibitors Used in the Treatment of Alzheimer's Disease: The Relationship Between Pharmacological Effects and Clinical Efficacy. Drugs Aging 2004, 21, 453-478. [CrossRef] [PubMed] 
13. Rosini, M.; Simoni, E.; Bartolini, M.; Cavalli, A.; Ceccarini, L.; Pascu, N.; McClymont, D.W.; Tarozzi, A.; Bolognesi, M.L.; Minarini, A.; et al. Inhibition of Acetylcholinesterase, $\beta$-Amyloid Aggregation, and NMDA Receptors in Alzheimer's Disease: A Promising Direction for the Multi-target-Directed Ligands Gold Rush. J. Med. Chem. 2008, 51, 4381-4384. [CrossRef] [PubMed]

14. Marco-Contelles, J.; León, R.; de los Ríos, C.; Guglietta, A.; Terencio, J.; López, M.G.; García, A.G.; Villarroya, M. Novel Multipotent Tacrine-Dihydropyridine Hybrids with Improved Acetylcholinesterase Inhibitory and Neuroprotective Activities as Potential Drugs for the Treatment of Alzheimer's Disease. J. Med. Chem. 2006, 49, 7607-7610. [CrossRef] [PubMed]

15. Vajragupta, O.; Boonyarat, C.; Murakami, Y.; Tohda, M.; Musatmoto, K.; Olson, A.J.; Watanabe, H. A novel neuroprotective agent with antioxidant and nitric oxide synthase inhibitory action. Free Radic. Res. 2006, 40, 685-695. [CrossRef]

16. Thiratmatrakul, S.; Yenjai, C.; Waiwut, P.; Vajragupta, O.; Reubroycharoen, P.; Tohda, M.; Boonyarat, C. Synthesis, biological evaluation and molecular modeling study of novel tacrine-carbazole hybrids as potential multifunctional agents for the treatment of Alzheimer's disease. Eur. J. Med. Chem. 2014, 75, 21-30. [CrossRef]

17. DeFeudis, F.; Drieu, K. Ginkgo Biloba Extract (EGb 761) and CNS Functions Basic Studies and Clinical Applications. Curr. Drug Targets 2000, 1, 25-58. [CrossRef]

18. Howes, M.-J.R.; Houghton, P.J. Plants used in Chinese and Indian traditional medicine for improvement of memory and cognitive function. Pharmacol. Biochem. Behav. 2003, 75, 513-527. [CrossRef]

19. Hage, S.; Kienlen-Campard, P.; Octave, J.-N.; Quetin-Leclercq, J. In vitro screening on $\beta$-amyloid peptide production of plants used in traditional medicine for cognitive disorders. J. Ethnopharmacol. 2010, 131, 585-591. [CrossRef]

20. Maneenet, J.; Daodee, S.; Monthakantirat, O.; Boonyarat, C.; Khamphukdee, C.; Kwankhao, P.; Pitiporn, S.; Awale, S.; Chulikhit, Y.; Kijjoa, A. Kleeb Bua Daeng, a Thai Traditional Herbal Formula, Ameliorated Unpredictable Chronic Mild Stress-Induced Cognitive Impairment in ICR Mice. Molecules 2019, $24,4587$. [CrossRef]

21. Tungmunnithum, D.; Pinthong, D.; Hano, C. Flavonoids from Nelumbo nucifera Gaertn., a Medicinal Plant: Uses in Traditional Medicine, Phytochemistry and Pharmacological Activities. Medicines 2018, 5, 127. [CrossRef]

22. Jung, H.A.; Karki, S.; Kim, J.H.; Choi, J.S. BACE1 and cholinesterase inhibitory activities of Nelumbo nucifera embryos. Arch. Pharm. Res. 2015, 38, 1178-1187. [CrossRef] [PubMed]

23. Oh, J.H.; Choi, B.J.; Chang, M.S.; Park, S.K. Nelumbo nucifera semen extract improves memory in rats with scopolamine-induced amnesia through the induction of choline acetyltransferase expression. Neurosci. Lett. 2009, 461, 41-44. [CrossRef] [PubMed]

24. Damanhouri, Z.A. A Review on Therapeutic Potential of Piper nigrum L. (Black Pepper): The King of Spices. Med. Aromat. Plants 2014, 03. [CrossRef]

25. Chonpathompikunlert, P.; Wattanathorn, J.; Muchimapura, S. Piperine, the main alkaloid of Thai black pepper, protects against neurodegeneration and cognitive impairment in animal model of cognitive deficit like condition of Alzheimer's disease. Food Chem. Toxicol. 2010, 48, 798-802. [CrossRef]

26. Hritcu, L.; Noumedem, J.A.; Cioanca, O.; Hancianu, M.; Kuete, V.; Mihasan, M. Methanolic Extract of Piper nigrum Fruits Improves Memory Impairment by Decreasing Brain Oxidative Stress in Amyloid Beta(1-42) Rat Model of Alzheimer's Disease. Cell. Mol. Neurobiol. 2014, 34, 437-449. [CrossRef]

27. Khalili-Fomeshi, M.; Azizi, M.G.; Esmaeili, M.R.; Gol, M.; Kazemi, S.; Ashrafpour, M.; Moghadamnia, A.A.; Hosseinzadeh, S. Piperine restores streptozotocin-induced cognitive impairments: Insights into oxidative balance in cerebrospinal fluid and hippocampus. Behav. Brain Res. 2018, 337, 131-138. [CrossRef]

28. Puttarak, P.; Dilokthornsakul, P.; Saokaew, S.; Dhippayom, T.; Kongkaew, C.; Sruamsiri, R.; Chuthaputti, A.; Chaiyakunapruk, N. Effects of Centella asiatica (L.) Urb. on cognitive function and mood related outcomes: A Systematic Review and Meta-analysis. Sci. Rep. 2017, 7, 10646. [CrossRef]

29. Chen, C.-L.; Tsai, W.-H.; Chen, C.-J.; Pan, T.-M. Centella asiatica extract protects against amyloid $\beta_{1-40}$-induced neurotoxicity in neuronal cells by activating the antioxidative defence system. J. Tradit. Complement. Med. 2016, 6, 362-369. [CrossRef]

30. Gray, N.E.; Harris, C.J.; Quinn, J.F.; Soumyanath, A. Centella asiatica modulates antioxidant and mitochondrial pathways and improves cognitive function in mice. J. Ethnopharmacol. 2016, 180, 78-86. [CrossRef] 
31. Harman, D. The aging process. Proc. Natl. Acad. Sci. USA 1981, 78, 7124-7128. [CrossRef]

32. Grundman, M.; Delaney, P. Antioxidant strategies for Alzheimer's disease. Proc. Nutr. Soc. 2002, 61, 191-202. [CrossRef]

33. Staehelin, H.B. Micronutrients and Alzheimer's disease. Proc. Nutr. Soc. 2005, 64, 565-570. [CrossRef] [PubMed]

34. Kumar, A.; Dogra, S.; Prakash, A. Neuroprotective Effects of Centella asiatica against Intracerebroventricular Colchicine-Induced Cognitive Impairment and Oxidative Stress. Int. J. Alzheimers Dis. 2009, 2009, 1-8. [CrossRef] [PubMed]

35. Blokland, A.; Geraerts, E.; Been, M. A detailed analysis of rats' spatial memory in a probe trial of a Morris task. Behav. Brain Res. 2004, 154, 71-75. [CrossRef] [PubMed]

36. Hasselmo, M.E. The role of acetylcholine in learning and memory. Curr. Opin. Neurobiol. 2006, 16, 710-715. [CrossRef] [PubMed]

37. Khan, H.; Amin, S.; Kamal, M.A.; Patel, S. Flavonoids as acetylcholinesterase inhibitors: Current therapeutic standing and future prospects. Biomed. Pharmacother. 2018, 101, 860-870. [CrossRef] [PubMed]

38. Hardy, J. The Amyloid Hypothesis of Alzheimer's Disease: Progress and Problems on the Road to Therapeutics. Science 2002, 297, 353-356. [CrossRef] [PubMed]

39. Blennow, K.; de Leon, M.J.; Zetterberg, H. Alzheimer's disease. Lancet 2006, 368, 387-403. [CrossRef]

40. Hampton, M.B.; Orrenius, S. Dual regulation of caspase activity by hydrogen peroxide: Implications for apoptosis. FEBS Lett. 1997, 414, 552-556. [CrossRef]

41. Pomytkin, A.I. $\mathrm{H}_{2} \mathrm{O}_{2}$ Signalling Pathway: A Possible Bridge between Insulin Receptor and Mitochondria. Curr. Neuropharmacol. 2012, 10, 311-320. [CrossRef]

42. Nakajima, Y.; Inokuchi, Y.; Nishi, M.; Shimazawa, M.; Otsubo, K.; Hara, H. Coenzyme Q10 protects retinal cells against oxidative stress in vitro and in vivo. Brain Res. 2008, 1226, 226-233. [CrossRef] [PubMed]

43. Ebert, U.; Kirch, W. Scopolamine model of dementia: Electroencephalogram findings and cognitive performance. Eur. J. Clin. Invest. 1998, 28, 944-949. [CrossRef] [PubMed]

44. Morris, R. Developments of a water-maze procedure for studying spatial learning in the rat. J. Neurosci. Methods 1984, 11, 47-60. [CrossRef]

45. Blainski, A.; Lopes, G.; de Mello, J. Application and Analysis of the Folin Ciocalteu Method for the Determination of the Total Phenolic Content from Limonium Brasiliense L. Molecules 2013, 18, 6852-6865. [CrossRef]

46. Chang, C.-C.; Yang, M.-H.; Wen, H.-M.; Chern, J.-C. Estimation of Total Flavonoid Content in Propolis by Two Complementary Colorimetric Methods. J. Food Drug Anal. 2002, 10, 5.

47. Songsiang, U.; Thongthoom, T.; Zeekpudsa, P.; Kukongviriyapan, V.; Boonyarat, C.; Wangboonskul, J.; Yenjai, C. Antioxidant activity and cytotoxicity against cholangiocarcinoma of carbazoles and coumarins from Clausena harmandiana. ScienceAsia 2012, 38, 75. [CrossRef]

48. Ellman, G.L.; Courtney, K.D.; Andres, V.; Featherstone, R.M. A new and rapid colorimetric determination of acetylcholinesterase activity. Biochem. Pharmacol. 1961, 7, 88-95. [CrossRef]

49. Levine, $\mathrm{H}$. Thioflavine T interaction with synthetic Alzheimer's disease $\beta$-amyloid peptides: Detection of amyloid aggregation in solution. Protein Sci. 2008, 2, 404-410. [CrossRef]

50. Boonyarat, C.; Yenjai, C.; Vajragupta, O.; Waiwut, P. Heptaphylline Induces Apoptosis in Human Colon Adenocarcinoma Cells through Bid and Akt/NF-kB (p65) Pathways. Asian Pac. J. Cancer Prev. 2015, 15, 10483-10487. [CrossRef]

51. Nair, A.B.; Jacob, S. A simple practice guide for dose conversion between animals and human. J. Basic Clin.Pharm. 2016, 7, 27-31. [CrossRef]

(C) 2020 by the authors. Licensee MDPI, Basel, Switzerland. This article is an open access article distributed under the terms and conditions of the Creative Commons Attribution (CC BY) license (http://creativecommons.org/licenses/by/4.0/). 